\title{
Towards Adaptation to Climate Change: Water for Rice in the Coastal Wetlands of Doñana, Southern Spain
}

\author{
Ana Iglesias $^{1} \cdot$ Berta Sánchez $^{1} \cdot$ Luis Garrote $^{2}$. \\ Iván López ${ }^{3}$
}

Received: 5 August 2014 / Accepted: 30 March 2015

(C) Springer Science+Business Media Dordrecht 2015

\begin{abstract}
Rice production in coastal wetlands provides critical ecosystem services that range from flood control to wildlife habitat. In the Iberian Peninsula rice was introduced in the 10th Century. Today Iberian rice accounts for about one quarter of the total rice production of the European Union, almost exclusively cultivated in the coastal wetlands of Spain, with permanent flooding. The intensive water management required to produce rice stands at a crucial point since freshwater supply is deteriorating at an unprecedented rate. Here we explore flexible adaptation options to climate change in the Doñana wetlands - a world heritage and biodiversity site - from two points of view: What are the policy options for agricultural water management in view of climate change? How can informed stakeholders contribute to better adaptation? The first question is addressed by simulating water availability to farmers with the WAAPA model under a range of adaptation policy options derived from the view of the local communities. The second question was addressed by means of participatory research. Adaptation options are framed according to the local environmental, social and policy context. Results suggest that perception on the potential role of new water infrastructure and farming subsidies dominates the view of local communities. The choices of the stakeholders that could be simulated with the hydrological model, were quantified in terms of additional water availability for the rice farming, therefore providing a quantitative measure to the qualitative solutions. Information provided during the study shaped the final adaptation options developed. Our research contributes to the definition of sustainable rice production in Europe.
\end{abstract}

Ana Iglesias

ana.iglesias@upm.es

1 Department of Agricultural Economics and Social Sciences, Technical University of Madrid (UPM), Madrid, Spain

2 Department of Hydraulic and Energy Engineering, Technical University of Madrid (UPM), Madrid, Spain

3 Department of Sociology, Universidad Complutense de Madrid (UCM), Madrid, Spain 
Keywords Coastal wetlands $\cdot$ Rice $\cdot$ Adaptation $\cdot$ Climate change $\cdot$ Doñana $\cdot$ Spain $\cdot$ Public participation

\section{Introduction}

The Europe 2020 strategy promotes the development of a greener, more environmentally friendly economy for the European Union countries. The European Environment Agency (EEA, 2012) supports the idea that healthy and resilient coastal ecosystems may provide services needed for this green economy whilst maintaining human well being. However, the challenge remains in defining how to move towards sustainability in practical terms. Coastal wetlands provide a challenging example that combines the economic interests of rice producers, the policy interests of rural development policies, and the environmental interests of water conservation policies.

The Doñana region is a coastal wetland in the Guadalquivir River Basin District of Southern Spain, where water is shared among the natural and the artificial wetland. The recent high temperature and drought episodes are influencing the view of local communities about the need for adaptation in the Doñana natural ecosystems and agricultural systems (De Stefano et al. 2014). The water district is already under environmental pressure (Willaarts et al. 2014; EEA 2012), the coastal vulnerability to sea level rise is high (Ramieri et al. 2011; Ojeda et al. 2009), and the potential increase of irrigation demand is very high (Iglesias et al., 2012).

Drought episodes of the past 50 years in the Sothern Europe aggravate the structural water deficit in the Doñana coastal wetland and the policy strategies undertaken have been capable to deal with extreme situations, but ineffective to solve the conflict among users, especially with the environment (Iglesias et al. 2008a; Iglesias et al., 2008b). Further, the water competition and conflicts will be increased due to a major pressure on freshwater resources as a result of climate change impacts, increased population, pollution problems from agriculture intensification and fragmented and uncoordinated adaptation policy strategies (Iglesias 2009). There is a need of reaching a balance among equity, economic security and the environment by flexible adaptation options that may deal with the increasing pressure on freshwater resources and in turn reduce the conflict among users in the case study region.

The local actors' views need to be considered for designing environmental policies since they may reveal a great deal of helpful information to approach possible adaptation pathways closer to the reality (Picketts et al., 2013). For instance, Sánchez et al. (2014a) found by public consultation that the main drivers to encourage the adoption of new mitigation and adaptation measures by Spanish farmers were pro-environmental concerns, financial incentives and access to technical advice. Furthermore, García-Llorente et al. (2011) found by public consultation in Doñana that the environmental policy strategies should be aimed to increase education programs regarding conservation policies specially addressed to male ageing population with lower education levels.

Several hundred studies have made significant efforts to find climate change adaptation measures (IPCC, 2014) and many in Doñana are contributing to the definition of strategies that can be agreed among the local actors (De Stefano et al. 2014), among the environmental policy design (Martín-López et al. 2011) and among the economic choices (Berbel et al., 2011). This paper aims to address the social and environmental challenges for adaptation of the Doñana coastal wetland. We combine two sources of information to explore flexible adaptation options for the rice farming and the natural ecosystem. First, we define the magnitude of the impacts 
and the effects of policy by modelling the river basin system. Second, we conduct a participatory data collection process to inform on the social challenge.

The study is organised in five sections. The next Section presents the methods and data; Section 3 provides an estimation of water availability under climate change and the effect of water policy scenarios; Section 4 analyses and discuses adaptation from the view of local communities. Section 5 concludes.

\section{Methods and Data}

\subsection{Study Area}

The Doñana coastal wetland is recognised of international importance and declared as a Ramsar Wetland, UNESCO World Heritage Site and Biosphere Reserve for being one of the richest natural ecosystems in Europe (García Novo and Marín Cabrera, 2006). The coastal wetland of Doñana is located in the lower part of the Guadalquivir River District (Southern Spain) on the Atlantic coast of Andalusia, the protected area cover an area of over 121,600 ha under the protection status of Doñana Natural Park and in the eastern side is also located the largest rice (Oryza sativa L.) farming area of the country (ca. 36,000 ha) (Fig. 1). There are a population of nearly 213,839 inhabitants in the Doñana area, whose activities are mainly addressed to agriculture and tourism and in turn the wetland provides key ecological services such as a stepping-stone in the migration route for birds and waterfowl, a home to many

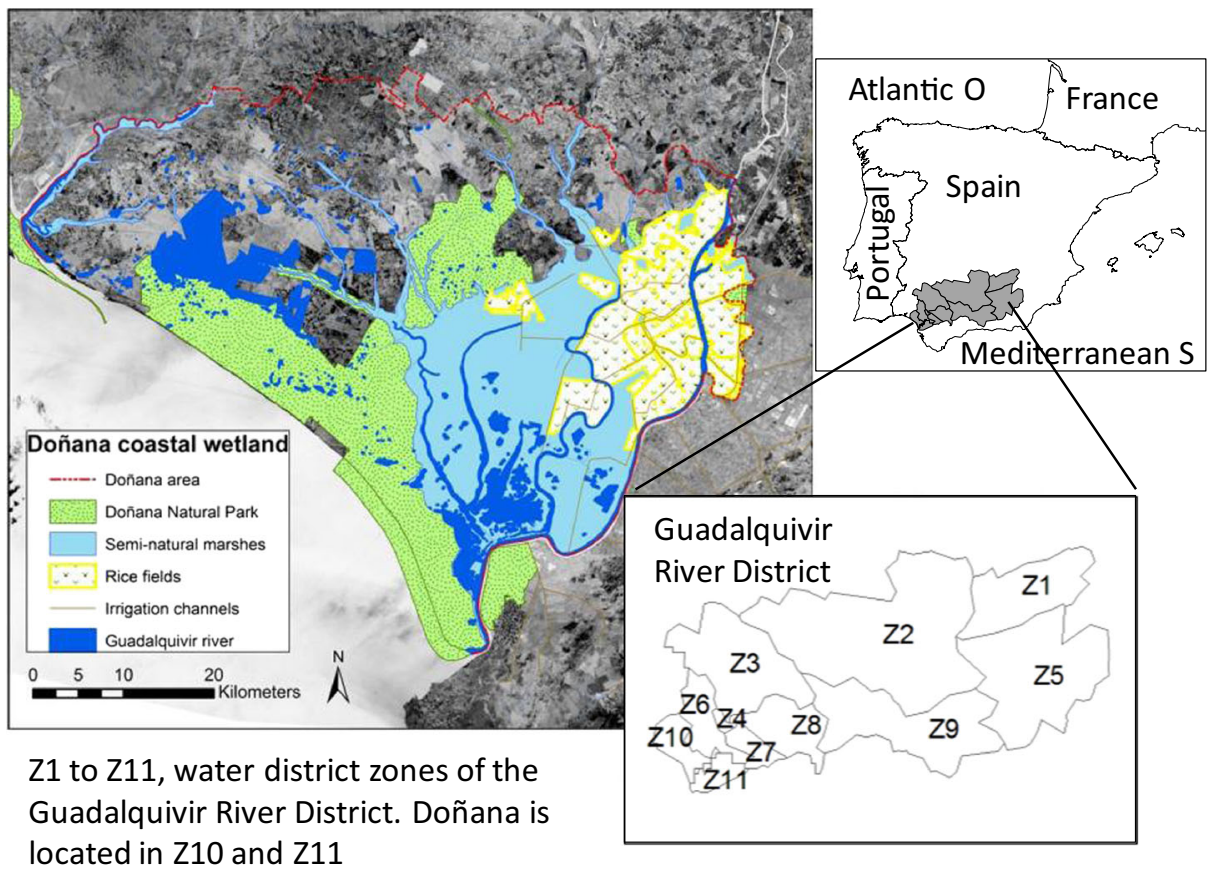

Fig. 1 Geographical location of the Doñana coastal wetland and the Guadalquivir River Basin District 
endemic and threatened species, regulation of the local hydrologic cycle and provision of landscape services (Martín-López et al., 2011).

The Guadalquivir River District with around $650 \mathrm{~km}$ of length and $57.527 \mathrm{~km}^{2}$ of area, amounts $7.022 \mathrm{hm}^{3} /$ year in average of renewable water resources from which $4,007.73 \mathrm{hm}^{3}$ / year are used mainly for agriculture $(87 \%)$, domestic use $(11 \%)$, industrial use $(1 \%)$ and energy (1\%) (CHG 2013). Rice farming is the main source of income for the local population but as well is one of the most water intensive crops of the river basin (De Stefano et al. 2014). Rice farming occupies the $4.2 \%$ of the irrigated area and requires over $10,400 \mathrm{~m}^{3} / \mathrm{ha} /$ year of water to achieve yields between 9 and $10 \mathrm{t} / \mathrm{ha}$, it accounts a total of $366 \mathrm{hm}^{3} /$ year, the $14.3 \%$ of the annual regulated water resources of the river basin (CHG 2013). The irrigation system for the rice cultivation consist in taking water directly from the Guadalquivir River and flooding the fields until $20 \mathrm{~cm}$ of water, depending on the crop needs for each development stage, throughout channels. The semiarid conditions and the salinity of soils make difficult the cultivation of many other crops in the rice area. The flooding irrigation system allows tolerable levels of oxygen, temperature and salinity for growing the rice (maximum concentration of $2 \mathrm{~g} / \mathrm{l}$ of salt in the water) whilst avoids the emergence of a saline crust in the top soil (Aguilar 2010). Further, the sea intrusion increases largely the salinity of the water in the estuary and the Guadalquivir Basin Authority has to provide for dam releases upstream from the rice area to improve the quality of irrigation water.

So far, rice farmers in Doñana received approximately $1,670 € /$ ha as public subsidies (within the framework of the CAP, Regulation EC/1782/2003) and if they met the integrated production commitment that includes a group of best management practices, they also received $398 € /$ ha (Regulation EC/1257/1999). Currently, rice farmers will have to meet the measures included into the CAP greening to perceive the equal subsidies. Thus rice production can be considered profitable for farmers since the average cost of producing rice in Doñana is over $1,496 € /$ ha (reduced due to a highly mechanized agricultural system and higher education training of farm managers that implement precision agricultural methods) and rice price usually ranges between 2,000-2,200€/ha on average (Aguilar, 2010).

The Doñana coastal wetland is a complex socio-ecological system where the rice production and the wetland ecosystem show a great dependence on water and climate and any change of these factors may alter the state of the environment and local livelihood security.

\subsection{Framework}

Our methodological framework combined two information sources to explore flexible adaptation options for the rice farming and the natural ecosystem in the coastal wetlands of Doñana (Fig. 2): First, the WAAPA model is used to estimate the effect of exposure to climate change and of different adaptation policy options in water availability, providing information on the environmental challenge. Second, semi-structured interviews and an expert panel, inform on the view of local communities on climate change risk and adaptation measures to rice production and the wetland, providing information on the social challenge.

Climate change is clearly defined in the WAAPA model, since it is an input for the simulations. The climate change scenarios for 2071-2010 are explained below. Although these climate scenarios are also presented to the stakeholders, it is inevitable that these scenarios are compared to the perceived current and past water scarcity and climate variability. It is important to notice that water scarcity is a permanent fact in the area and climate scenarios intensify the scarcity level. 


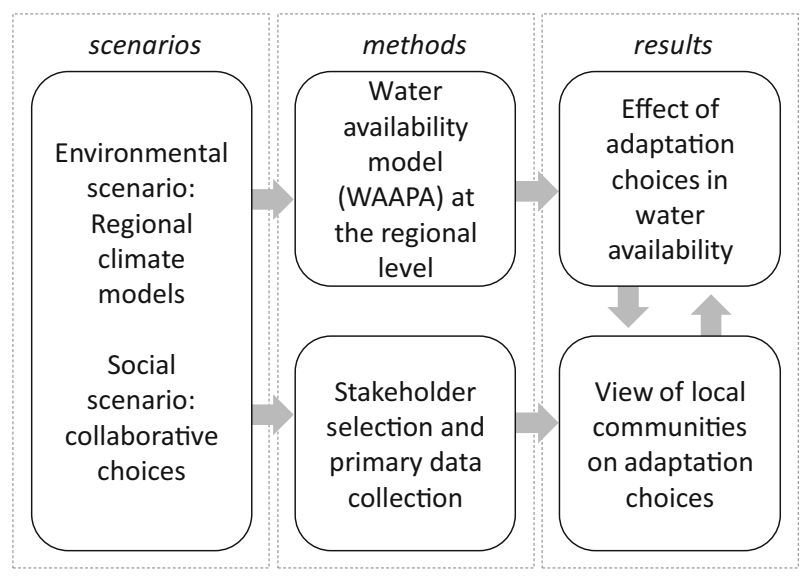

Fig. 2 Methodological framework

\subsection{Modelling Water Availability and Policy Scenarios}

The effect of climate change and policy on water availability for irrigation and for the natural ecosystem was estimated with the WAAPA model (Garrote et al. 2011; Garrote et al. 2015). The quantitative analysis provided support for the selection of adaptation policy options that inform local stakeholders.

The WAAPA model (Water Availability and Adaptation Policy Analysis) calculates Maximum Potential Water Withdrawal (MPWW), defined as the maximum water demand that could be provided at a given point in the river network with the available water infrastructure (i.e., reservoirs, dams and water transfers), satisfying management and environmental constraints. MPWW is associated to a given demand type, which implies a minimum required reliability and certain seasonal variation. In all cases urban supply is associated to population and has higher priority than irrigation. Water for ecosystems has also a higher priority than irrigation: The amount of water allocated for ecological flows is defined in each sub-district following the specification of the national regulation on hydrological planning.

Model architecture is summarized as follows: (a) Satisfaction of the environmental flow requirement in every reservoir with the available inflow. Environmental flows are passed to downstream reservoirs and added to their inflows. (b) Computation of evaporation in every reservoir and reduction of available storage accordingly. (c) Increment of storage with the remaining inflow, if any. Computation of excess storage (storage above maximum capacity) in every reservoir. (d) Satisfaction of demands ordered by priority, if possible. Use of excess storage first, then available storage starting from higher priority reservoirs. (e) If excess storage remains in any reservoir, computation of uncontrolled spills.

The MPWW analysis was applied to estimate the exposure of the Guadalquivir sub-districts to climate change. The comparison between the MPWW for irrigation in the control and in the climate change scenario provides a proxy variable to estimate exposure to climate change. In this study we consider that urban demand is fixed, because it is linked to population, which in the region under analysis is not expected to change significantly in the next 50 years (OECD 2012). Water for ecosystems is estimated following the environmental flow requirements specified in the national regulation, which establishes a range between the 5 and $15 \%$ quantiles 
of the marginal distribution of monthly flows in current natural conditions. The central value, $10 \%$, was adopted and it was considered constant. According to climate change projections, this assumption may be perceived as conservative, since streamflow is expected to decrease sharply in the region, but it may underestimate or overestimate future ecosystem water demand depending on future land use and environmental regulations.

Water policy scenarios are constructed aiming to maintain adequate reliability for urban, ecosystem and irrigation demands. The effect of the adaptation effort is estimated from the difference between water availability for irrigation in the control and in the climate change scenario. This is based on the assumption that in the control period irrigation demand is similar to MPWW for irrigation. The assumption is well grounded for the study region, a water scarcity Mediterranean region, where water resources are developed (i.e., infrastructure and management) to satisfy existing demands. The larger the difference between current and future water availabilities for irrigation, the greater the adaptation policy effort required to compensate for climate change though adaptation.

The effect of policy scenarios here is calculated as the increase in future water availability resulting from the implementation of each policy. This study considers four adaptation policy scenarios aiming to reduce the irrigation demand that would be required in the climate change scenario in order to restore the same level of performance that is observed in the control scenario. Demand reduction is not the only policy alternative to reach the objective of adequately supplying the multiple demands of water in the area. In addition to demand reduction, this study considers four adaptation policy measures. Policy option 1 (urban policy) implies to improve urban water use efficiency and reach the target of $175 \mathrm{l} /$ person/day supplied in urban areas. Currently this amount is $300 \mathrm{l} /$ person/day, a value that is considered too high. Concrete examples for implementing this policy could be re-use of urban water or improvement of water technical efficiency within cities (supply management policy), imposed reduction of water per capita use (demand management policy), or water rights exchange programs (supply management policy). The data on urban water use of $300 \mathrm{l} / \mathrm{pd}$ is the reference value adopted in the Hydrological Plan of the Guadalquivir River Basin District in time horizon 2015 (taken as "current" scenario) (CHG 2013). The value of $175 \mathrm{l} / \mathrm{pd}$ is taken as a target value estimated from the water supply systems in Spain that currently show the smallest percapita consumption reported (value 195 1/p.d in the Consorcio de Aguas de Tarragona, plus a further $10 \%$ increase in efficiency) (CHE 2014).

Adaptation Policy 2 implies a reduction of the environmental flow requirements (from the 10 to $5 \%$ quantile of the marginal monthly distribution of runoff). This assumption is clearly challenged within the current strategy for water management, but it is included here to illustrate the trade-off between water for the artificial wetland and for the natural wetland for the discussion among local actors. Adaptation Policy 3 implies to use the storage available in hydro-power dams for regulating water for irrigation. Finally, Adaptation Policy 4 is reached by improving the overall water management of the system by expanding the network of water interconnections and applying water resources systems optimization models.

In this study, climate change scenarios are derived from Regional Climate Models (RCM) driven by two greenhouse gas emission scenarios. The use of RCMs is an important tool for evaluating water management under future climate change scenarios (Varis et al. 2004). Nonetheless, it is well known that the output of the RCMs cannot be used directly if there is no procedure that eliminates the existing bias (Sharma et al. 2007). For this reason, in order to analyse the effect of climate change on water availability for irrigation in a regulated system, here we generate climate change projections based on the bias-corrected runoff alternatives 
(following Gonzalez-Zeas et al. 2012). We use two emission scenarios (A1B and E1, to represent the uncertainty derived from greenhouse emissions policies) and two regional climate models to represent the uncertainty derived from model choice). Climate change input for the WAAPA model was monthly time series of streamflow data obtained from the results of the ENSEMBLES project in two climate scenarios (Table 1). The transient runs (1950-2100) were split in two periods: control climate (1960-1990, Oct 1961 to Sep 1991) and future climate (2070-2100, Oct 2069 to Sep 2099).

\subsection{Criteria for Selecting Stakeholders and Sample Size}

Since the mid 1980s there is a growing awareness that the stakeholder may be crucial for effective change and adoption of innovation (Freeman 1984; Eden and Ackermann 1998; Bryson 2004). The fundamental principle is that there are a number of people, organisations and groups, who are critical to the adaptation viability and success. There has been a great deal written in the stakeholder literature on the definition of who or what is a stakeholder. There are numerous definitions of stakeholders; here we consider that stakeholders are groups of individuals with power to directly affect the adaptation future either by supporting or constraining actions (adapting the business definition of Eden and Ackermann (1998) to the adaptation objectives) and recognise that the stakeholders' views will change depending on the specific issue that is being addressed (see Cummings and Doh 2000; Glicken 2000). Following these concepts, we selected stakeholders in two steps: (1) Identification of the groups who have the potential to affect or may be affected by adaptation policies; and (2) Analysis of their power or influence in the adaptation decision in an influence vs interest map (Eden and Ackermann 1998).

Power versus interest grids typically help determine which players' interests and power bases must be taken into account in order to address the problem or issue at hand. As result we grouped the stakeholders in a matrix with four categories (Fig. 3). First, the critical players are the farmers, since they have high influence and high interest. Second, the context setters are the policy makers, which have high power but lower interest. Third, the significant players are the environmental groups, which have high interest and lower power. Finally, the citizens' group includes the less significant players, with lower interest and lower power. Recognising the importance citizens' opinion for setting values in adaptation, we assumed that the expert scientist group could represent an aggregated view of the population (see below). This assumption is clearly flawed, but may be valid in the absence of data derived from a large survey, that is completely out of the scope of this study. Therefore the views of the expert panel

Table 1 Climate change scenarios used as input to the WAAPA obtained from the ENSEMBLES project

\begin{tabular}{|c|c|c|c|c|c|}
\hline $\begin{array}{l}\text { Scenario name } \\
\text { in this study }\end{array}$ & $\begin{array}{l}\text { Global } \\
\text { model }\end{array}$ & $\begin{array}{l}\text { Regional } \\
\text { model }\end{array}$ & $\begin{array}{l}\text { Resolution and } \\
\text { time frame }\end{array}$ & $\begin{array}{l}\text { ENSEMBLES } \\
\text { file }\end{array}$ & $\begin{array}{l}\text { Socio economic } \\
\text { assumptions }(*)\end{array}$ \\
\hline CRNM A1B & ARPEGE & RM5.1 & $\begin{array}{l}25 \times 25 \mathrm{~km}, \\
1950-2100\end{array}$ & $\begin{array}{l}\text { CNRM-RM5.1_SCN_- } \\
\text { ARPEGE_MM_25km_ } \\
\text { 1950-2100_mrro.nc }\end{array}$ & A1B \\
\hline KNMI A1B & ECHAM5-r3 & RACMO2 & $\begin{array}{l}25 \times 25 \mathrm{~km}, \\
1950-2100\end{array}$ & $\begin{array}{l}\text { KNMI-RACMO2_A1B_ } \\
\text { ECHAM5-r3_- } \\
\text { MM 25km mrro.nc }\end{array}$ & $\mathrm{A} 1 \mathrm{~B}$ \\
\hline
\end{tabular}

(*) See Nakicenovic et al. 2000 


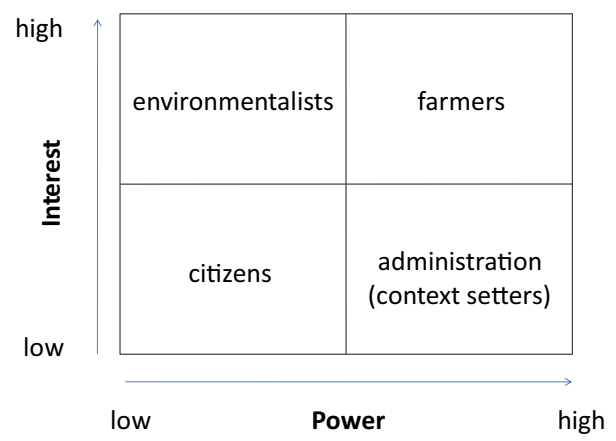

Fig. 3 Criteria for selecting stakeholder groups, adapted from the theoretical power versus interest grid of Eden and Ackermann (1998)

are not formally considered in the study; the reason to include this group in the description is to communicate the research process.

Once the groups were defined, deciding who should be involved is a key strategic choice. In general, people should be involved if they have information that cannot be gained otherwise, or if their participation is necessary to assure successful implementation of adaptation strategies. These two aspects, together the available volunteer participants, guided the selection of stakeholders for the one-to-one long interviews (see Appendix 1).

In all groups, the number of available volunteer participants was very low, limiting the potential sample size. This raises the question of the representation of the sample. In relation to the representation, it is recognised good results can be achieved with just a few interviews, as data become saturated, and data analysis indicates that all themes can reach saturation, meaning additional participants would likely not have added to the depth or breadth of parent responses (Sandelowski 1995a, 1995b; Carlsen and Glenton 2011).

In this study area, the position of the farmers is extremely well defined, since all want to maintain or increase the water supply for rice cultivation. Over $90 \%$ of rice farmers in Doñana belong to farmer associations (i.e., Farmer Association body, such as Farmers Advisory Services, Irrigation Communities, Cooperatives or Rice Farming Federations and Unions; see Aguilar 2010). These services include only private members with a technical profile or experienced farmers, and do not include representatives of the local or regional administration. The rice farmer associations provide services to manage irrigation, to the processing of rice after harvest and to facilitate the marketing to the farmers. They also offer technical advice and legislative information, including regular supervision and follow-up of the rice fields and production. The high level of association between rice farmers makes them a strong lobby with very uniform interests. For the interviews we selected members from the five organisations that represent $90 \%$ of the farmers, with the aim of providing the representation of the rice farmers in the area as accurate as possible. The Administration body refers to the public service organization which has control on water resources policy, water management and irrigation planning in the Guadalquivir River Basin District. It includes the River Basin Authorities and public officials, with almost absolutely uniform view on the possible solutions facing climate change. The environmentalist body is a lobby group representing the environmental rights and the nature welfare of the Doñana coastal wetland by strategic actions in water management and new regulations; this group has a uniform voice since the 1960 s claiming more water for the natural wetland. 


\subsection{Primary Data Collection}

Primary data on observed impacts in the coastal wetland and possible adjustments in view of climate change was collected by means of two qualitative social research methods used in sequence: semi-structured interviews and an expert panel. These are sampling techniques commonly used in policy research (Martín-López et al., 2011; Harrell and Bradley 2009; Ingram and Morris 2007).

Semi-structured interviews were conducted with a standardized guideline to ensure that the researcher covers the material and with an open framework with some discretion about the order in which questions were asked. This sampling method is adequate when the objective is to look deeply into a topic and to understand thoroughly the answers provided (Harrell and Bradley 2009). The interviewer provided information about climate change impacts on water resources in the Guadalquivir River Basin District (included in the Results section) and received information about the observed changes in the coastal wetland and potential adjustments of current water management that affects rice production and the natural ecosystem. In particular, the interview aimed to identify the flexible adaptation measures that could be effective from the social and environmental points of view. A guideline to the interviews was prepared in advance (Appendix 1), however the interviews resulted in additional discussion topics that contribute to understand the barriers to implement the potential technical measures.

The semi-structured interviews aim to obtain specific qualitative information about observed climate impacts and possible adjustments from a sample of the population. The main advantage of the method is that it encourages two-way communication, those being interviewed can ask questions to the interviewer, provides arguments for answers, and encourages discussion on sensitive issues. The main limitations are derived from the small sample size and the lack of trust that the interviewed may have about the confidentiality of the responses.

The expert panel assisted in the formalisation of the research questions derived from the semi-structured interviews. The interview survey was conducted during 31 January, 1 and 2 February 2012. To supply a broad outline on observed climate impacts and possible adjustments, eleven key participants from relevant sectors of the coastal wetland were encouraged to give their input (Table 2). The requirements for the participants' selection were: i) to be working on activities related to the rice production and the natural ecosystem during the last decade; ii) to have an extensive knowledge about the rice productive sector and to have regular contact with the rice farmers; ii) to have an extensive knowledge about the welfare of the wetland and the natural ecosystem functioning; and iii) to be informed on the water management requirements to cope successfully with the rice production and the natural ecosystem.

The resulting information of the consulting process was also used to inform local stakeholders of the rice farming area by organizing two workshops about the local climate change risk and adaptation with a total of 51 participants (De Stefano et al. 2014).

\subsection{Limitations of the Methodology}

There are some major limitations of our methodology, derived from the modelling approach and from the consultation process.

The simulation of water availability under climate and policy changes with the WAAPA models have major sources of uncertainty and limitations. The streamflow were derived from 
Table 2 Description of the public consulting conducted in terms of type of consultancy, number of participants and structure of the sample

\begin{tabular}{lccc}
\hline Type of consultancy & Date and venue & $\begin{array}{c}\text { Number of } \\
\text { participants }\end{array}$ & Type of participants \\
\hline $\begin{array}{c}\text { Semi structured individual } \\
\text { interviews to local actors }\end{array}$ & $\begin{array}{c}\text { 31 January to 2 February, } \\
2012 \text { in Doñana area }\end{array}$ & 11 & $\begin{array}{c}\text { Farmer Association (5), } \\
\text { Administration (3), } \\
\text { Environmentalists (3) } \\
\text { Expert panel to experts / } \\
\text { scientists }\end{array}$ \\
\hline
\end{tabular}

the output of regional climate models that include a very crude representation of the hydrological cycle, demands are estimated using globally available data as proxy variables. This is fully explained in Garrote et al. (2015). In addition changes in land use consistent with the climate scenario projections have not been included in the simulations, since the aim was to simulate policy choices for the current wetland system.

A major limitation is derived from the consultation process. Although the three groups of participants selected are reasonably in line with adaptation in the case study, the interview sample is quite small and it is not necessarily representative of all the communities and organizations involved. The study did not address the full range of stakeholders which affect or are affected by climate change adaptation. Here the groups included are likely to have a potential interest and influence in the decision making process of an adaptation strategy, but some actors may be missing due to the limitations in the sample size. A derived shortcoming of the consulting process arises from the current level of conflict between stakeholders having different views on water management. This may have resulted in some degree of mistrust on the confidentiality of their responses. In addition, the consulting process applied in this study only included qualitative information, resulting in difficult comparison among responses and limited in capturing variability among the respondents. The open questions of the semistructured interviews did not provide enough information for a quantitative analysis. Thus, we identified a portfolio of adaptation options for water resources management rather than seeking consensus on the more cost effective option or priority that could be derived from more quantitative data. Further research is needed in order to incorporate the local knowledge into climate change adaptation local plans and in the wider policy context.

Despite these uncertainties and limitations, the results obtained show a qualitative picture for future water availability in the Guadalquivir basin under a choice of adaptation policy options derived from the consultation. Our findings advance the knowledge of differing climate change strategies at local scale by providing increased comprehension of the stakeholders oppose or support to adaptation options which could be used to incorporate in local adaptation plans.

\section{Water Availability and Potential Policy Choices}

Climate change jeopardizes the equilibrium of water resources in the Guadalquivir water district and the impacts will vary as a result of local regulation capacity (Fig. 3). The difference between runoff and water availability is defined by the effect of storage. Reservoir regulation is one of the most important water resources management policies in water-scarcity areas and has 
generated significant impacts. Existing reservoirs are being subjected to intense multiobjective demands on limited resources (i.e., water supply, flood control, hydropower, navigation, fish and wild life conservation, recreation, and water quality by assimilating waste effluents.)

These scenarios of water availability (Fig. 3) demonstrate that in water scarcity regions, water availability is likely to be one of the great future challenges. Defining future water availability under different adaptation policy options is therefore a basic step for water policy formulation.

Reductions of water runoff and increased variability, resulting from exposure to climate change, will lead to significant decreases in the water availability (Fig. 3). This clearly demands for adaptation policy measures. Here we only consider impositions of demand restrictions since regulatory capacity is already at a maximum in the river district. This is particularly true in the case of irrigation water demand scenarios since it is reasonable to assume that, without changes in policy, land use or technology, projected irrigation demand in the basin will be higher than present irrigation demand even if farmers apply efficient management practices and adjust cropping systems to the new climate. Moreover, when policy and technology remain constant, it has been shown that agricultural water demand will increase in all scenarios in the region (Iglesias et al., 2007, Iglesias 2009). The main drivers of this irrigation demand increase are the decrease in effective rainfall and increase in potential evapotranspiration (due to higher temperature and changes of other meteorological variables).

\section{The View of Local Communities: Main Risks and Local Adaptation Options}

Here we present the results of the consulting process (with key local actors and the experts) focusing on a) how the accelerated state of climate change is already affecting the rice production and the natural ecosystem and b) what are the main conflicts and the potential opportunities for societal consensus on local adaptation options.

The results were first generalized into appropriate categories using the topics included in the interview guideline in Appendix 1 and expanded in Appendix 2. The categorization was conducted by the primary researcher, and then assessed and verified by other researchers and the experts. Table 3 synthesizes the interviews results. The local actors' views fell into the following categories: (1) risks derived from changes in the climate and degree of social concern on them and (2) local adaptation options according to the identified risks. In this second category, we characterise the: current implementation level per adaptation option identified; acceptance (green) or rejection (red) of the local adaptation options by farmers associations; acceptance (green) or rejection (red) of the local adaptation options by environmentalists; and support for (green) or rejection of (red) the local adaptation options from the administration. The white cells make reference to "no opinion" answers.

The first category describes stakeholders' perception on the risks derived from changes in the climate and the degree of social concern to them. The results of the interviews suggest that that the major risks in the case study area are water scarcity, salinity problems in water and soils, and to a lesser extent increased invasive species and pests and decreased rice yields and quality. Most respondents' perceptions stemmed from the scarcity of water as the main risk to be concerned. A possible reason why water scarcity is perceived to be the most important risk is the fact that it can easily lead to fall of productivity and rice yield reductions and in turn 
Table 3 Summary of the view of local actors on climate change risks and adaptation options

\begin{tabular}{|c|c|c|c|c|c|}
\hline $\begin{array}{l}\text { Risk derived from } \\
\text { changes in the } \\
\text { climate / Degree of } \\
\text { social concern }\end{array}$ & Local adaptation option & 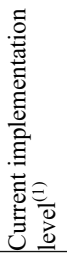 & 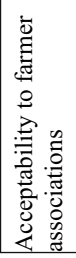 & 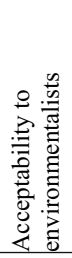 & 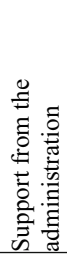 \\
\hline & \multicolumn{5}{|l|}{ I. Technological measures to face the risk } \\
\hline \multirow{5}{*}{$\begin{array}{l}\text { Increased water } \\
\text { scarcity /High }\end{array}$} & Water recirculation and reutilization within the paddy rice & M & & & \\
\hline & Increase the technical efficiency of the irrigation systems & $\mathrm{L}$ & & & \\
\hline & Installation of flow meters & $\mathrm{L}$ & & & \\
\hline & Laser levelling & $\mathrm{H}$ & & & \\
\hline & Additional water infrastructure & n.a. & & & \\
\hline \multirow[t]{2}{*}{$\begin{array}{l}\text { Increased water } \\
\text { salinity /High }\end{array}$} & Water releases from upstream reservoirs & M & & & \\
\hline & $\begin{array}{l}\text { New pipeline to bring in the water directly upstream from the } \\
\text { salt water intrusion }\end{array}$ & n.a. & & & \\
\hline \multirow[t]{2}{*}{$\begin{array}{l}\text { Increased soil } \\
\text { salinity/High }\end{array}$} & Flooding irrigation systems to wash soils & $\mathrm{H}$ & & & \\
\hline & Organic production (good farming practices) & $\mathrm{L}$ & & & \\
\hline $\begin{array}{l}\text { Increased invasive } \\
\text { species and pests } \\
\text { /Medium }\end{array}$ & Integrated production (inputs use efficiency) & $\mathrm{H}$ & & & \\
\hline \multirow[t]{3}{*}{$\begin{array}{l}\text { Decreased rice yield } \\
\text { and quality /Low }\end{array}$} & New longer cycle rice varieties & $\mathrm{L}$ & & & \\
\hline & New rice varieties adapted to water and heat stress & $\mathrm{L}$ & & & \\
\hline & \multicolumn{5}{|l|}{ II. Organizational measures to face the risk } \\
\hline \multirow[t]{6}{*}{ All risks /High } & Reduction of the available cultivated surface & $\mathrm{L}$ & & & \\
\hline & $\begin{array}{l}\text { Crop diversification and diversification to others activities } \\
\text { (e.g. aquaculture, agro-tourism) }\end{array}$ & $\mathrm{L}$ & & & \\
\hline & Anticipating local and regional water shortages & $\mathrm{L}$ & & & \\
\hline & $\begin{array}{l}\text { Increase monitoring and information on water use and } \\
\text { availability at local level }\end{array}$ & $\mathrm{L}$ & & & \\
\hline & Setting of irrigation turns & M & & & \\
\hline & \multicolumn{5}{|l|}{ III. Governance measures to face the risk } \\
\hline \multirow[t]{8}{*}{ All risks /High } & $\begin{array}{l}\text { Actions at the basin level leading flexible adaptation } \\
\text { strategies to climate change }\end{array}$ & $\mathrm{L}$ & & & \\
\hline & $\begin{array}{l}\text { Improve transparency and public participation to encourage } \\
\text { agro-environmental awareness }\end{array}$ & $\mathrm{L}$ & & & \\
\hline & Increase scientific research, field studies, dissemination & M & & & \\
\hline & Improve coordination between institutions, data sharing & $\mathrm{L}$ & & & \\
\hline & Encourage a long-term perspective in water management & $\mathrm{L}$ & & & \\
\hline & Implement good practices defined in the WFD & M & & & \\
\hline & Increase in farmers training and technical advice & M & & & \\
\hline & Supplemental transfer water from the Guadiana new riverbed & n.a. & & & \\
\hline
\end{tabular}

provoke biodiversity losses. The foresee sea level rise projections in the coastal wetland are expected to worsen the water quality in the lower part of the Guadalquivir River Basin, the 
case study area, due to larger marine intrusion (IPCC 2014; Ramieri et al. 2011; Ojeda et al. 2009). An increased relative water scarcity, together with higher levels of salinity, makes rise conflicts and competition among users over the allocation of water (Rijsberman 2006).

The literature review and the findings of this study suggest that higher temperatures are also expected to change water demands and have direct physical effects on the plant growth and development (IPCC 2013, Hanak and Lund 2012). Pulido-Calvo et al. (2012) found that in dry periods a mean temperature increase of $1{ }^{\circ} \mathrm{C}$ in low altitude locations of the Guadalquivir River Basin will result in a mean increase of $12 \%$ in the irrigation demand on outflows. Rice is particularly sensitive to heat stress and may suffer serious damages during the anthesis to maximum temperatures above $37^{\circ} \mathrm{C}$ and especially when it is exposed to water stress during the entire flowering stage (Sánchez et al. 2014b). Although the expected mid and long-term scenarios of high temperatures are not recognize as a relevant risk by responses of farmer associations, they are already changing the rice growing calendar and introducing new varieties which are more tolerant to heat stress and longer cycle rice varieties (e.g., J-sendra 155 or Puntal 145).

In a qualitative way, the farmer associations responses reflected that farmers in the Doñana coastal wetland: (i) are likely more concerned about the present than about the future; (ii) are very aware of the damage of current climate extremes in rice production and the natural ecosystem, although they do not entirely recognise that the intensification of current extremes may be a consequence of the climate change; (iii) probably do not perceive increased climate variability as a risk to be concerned in the long-term, since they have a shot-term view more addressed to profit-driven principles than to those related to climate change; and (iv) are likely more concerned about severe droughts or salinity since they have faced these events over the years. Rice farmers have demonstrated to have good adaptation capacities to current and past extreme events, but they do not seem to be particularly open to innovation for the forthcoming risks linked to climate change.

Forming the second category, the respondents provided a broad spectrum of local adaptation options for the rice production to face the identified risk. We organize them into three main groups: technological, organizational and governance measures. The following categories are related to the current implementation level of the options, farmer associations and environmentalists' acceptability and administration support per option.

Different points of views about the adaptation options were stated depending on the type of participants. Almost half of adaptation options included in Table 3 confront farmer associations and environmentalists' views, since the options may not be fully corresponding to their own interests and goals. Farmer associations try to promote technological and governance measures that involve options to build new water infrastructures (e.g., a pipeline to bring in the water directly upstream from the salt water intrusion) or increase the water supply to the rice crops (e.g., water releases from upstream reservoirs or supplemental transfer water from the Guadiana new riverbed). So far, environmentalists and administration have null acceptance and support from those options that may result in higher economic costs and environmental impact of new infrastructures. In the perception of the farmer associations, measures that may imply lower yields (organic production, rice varieties adapted to climate change) or reductions of the cultivated area should not be accepted. However, Pulido-Calvo et al. (2012) results supported that the current water deficit in the Guadalquivir River Basin may inevitably lead to reductions in irrigated areas. Environmentalists agree with this projection, but the administration seems not willingness to support the change of management or activity. 
Technological measures to increase water efficiency at the field level were most likely to be accepted for both farmer associations and environmentalists. For instance, water recirculation and reutilization within the paddy rice or increased technical efficiency of the irrigation systems. Other technological options that have already proven benefits to the rice production and are widely implemented in the area (laser levelling and integrated production) were also fully supported by the administration. Rice farming in the Doñana wetland is characterized to be a highly mechanized agricultural system with qualified labour that uses precision agricultural methods (Aguilar 2010; De Stefano et al. 2014).

Organizational measures related to water management were positively perceived by the farmer associations and environmentalists. Their responses reflected that there is a lack of local monitoring and information on water availability and use. The provision of accurate, accessible and useful water information at different scales is essential to deal with reductions in water availability (Wei et al. 2011). Reed et al. (2006) reported that including thresholds information about the risks at local scale, even when they are difficult to identify, they can further improve the value of monitoring in managed ecosystems. In the perceptions of the two groups, farmer associations and environmentalists, there is also a need of anticipating management options to local water shortages. Once problems have arisen, reactive management efforts can be more costly than anticipating management to reduce risk by actions to enhance the resilience of the river basin (Palmer et al. 2008). Proactive management efforts may include among others: management plans to the risk of water scarcity at the farm level, on-farm reservoirs, improvements in water use efficiency (Iglesias et al. 2007) and, the establishment of water markets to negotiate water between water users and in turn encouraging the reallocation of water rights to restore freshwater ecosystem health (Garrick et al. 2009; Rey et al. 2014). The high number of "no opinion" answers obtained within the category of "administration support" to technological or organizational options is striking. It suggests to some extent a limited commitment to measures addressed at farm or local scale on this topic. Most of questions concerning to governance options were perceived to be supported by the administration, since it directly fall in their scope of action.

Governance measures included options addressed to improve the coordination between institutions. The critical importance of institutional good governance has been previously established as a requirement for the regional adaptation capacity by preceding research (Berrang-Ford et al. 2014; Hanak and Lund 2012; Iglesias 2009). Increase scientific research, farmer training and technical advice were governance options perceived positively by all the groups. Finally, a lack of confidence in the truth or efficacy of governance measures addressed to climate change strategies and environmental awareness is often referred in the farmer associations' responses. These results prove that climate change and environment can be concepts which are not be easily grasped, and tends to be something that is less tangible to farmers. Experts also pointed out the need of encouraging the farmers' long-term views by climate change advisement and capacity building.

Overall, the results from the consulting process stressed the difficult to find adaptation options which are concurrent for the farmer associations, environmentalists and administration preferences. The spectrum of potential adaptation options in the case study can be represent from two end points, the purely environmental one (eco-centric perspective addressed to reduce impacts on the Guadalquivir River resources and the conservation of natural ecosystems), and the fully agricultural (technocratic perspective addressed to ensure rice yields and productivity) (Figs. 4 and 5). If possible, policy makers and researchers should try to encourage more flexible adaptation options or those located in the middle of the spectrum where environmental and agricultural profit-driven preferences are closer. The international competition in a globalized sector together with the new environmental requirements from 


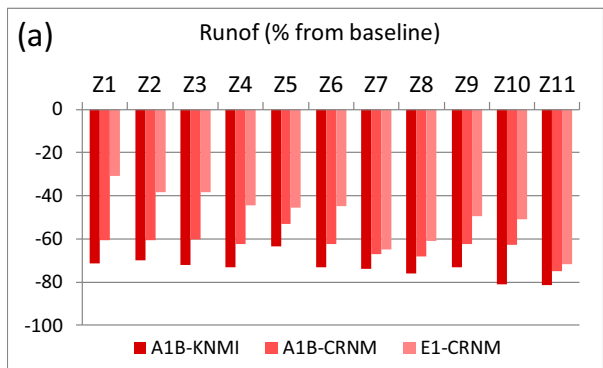

(b) Water availability - No Adaptation (\% from baseline)
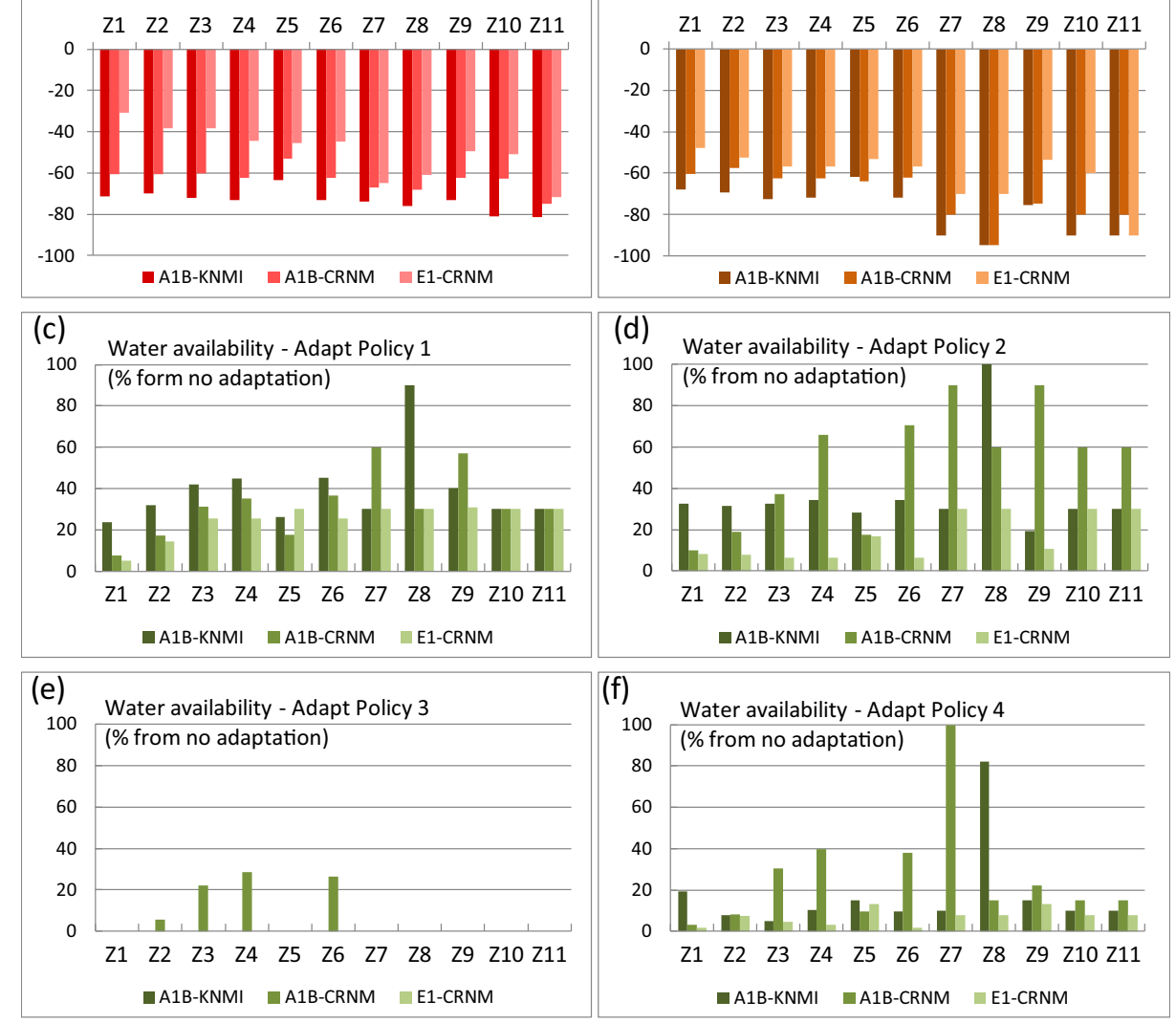

Fig. 4 Effect of climate change scenario (2070-2100) with respect to control run (1960-1990) for the RCM models forced with two emission scenarios in the Guadalquivir water district. (a) Per unit reduction of runoff; (b) water availability for irrigation with current policy; (c) water availability for irrigation with improved water policy in urban areas; (d) water availability for irrigation with water reduced allocation for environmental uses; (e) water availability for irrigation with hydropower reservoir water conservations; (f) water availability for irrigation with improved the overall water management of the system by water interconnections

CAP might bring more pressure, raising the current conflicts between water users in the area (De Stefano et al. 2014). The portfolio of adaptation options and initiatives will probably fail if policy makers and advisors do not empower and inform local actors (Jones 2010). Additionally, there is a need of adaptation options that in turn are able to mitigate climate change by having less favourable energy implications (Hanak and Lund 2012).

\section{Potential Policy Interventions based on the Interrelation of the two Results}

The interrelation of the qualitative and quantitative components of the study is a challenge. Our approach to interrelation is summarised in Table 4 and includes three steps. The first step is the characterisation of water shortages under climate change by the WAAPA model. This diagnostic step is a quantification of the potential water availability changes in the basin and in 


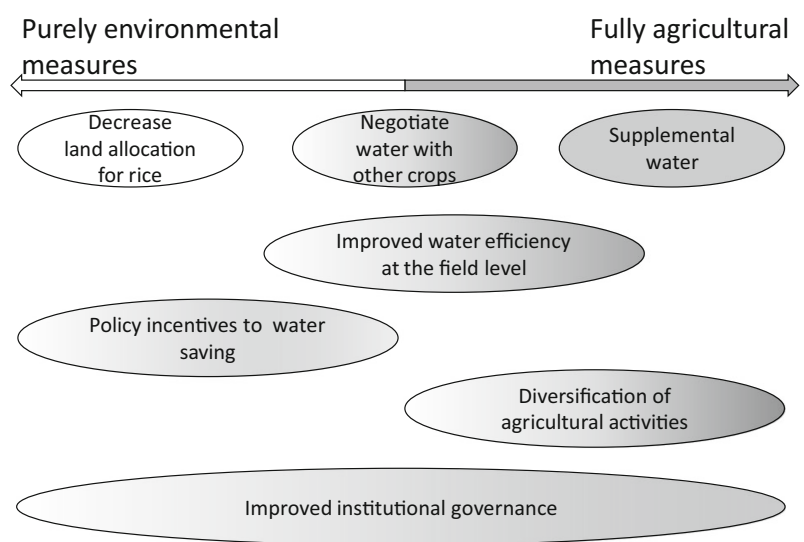

Fig. 5 The spectrum of potential adaptation options to climate change for the case study

Doñana, in particular. The broader scale is necessary, since the changes at the local level - and the potential solutions - depend on the changes in the basin. The simulations of water availability changes in all sub-basins range from -45 to $-93 \%$ of current water availability.

The second step explores the choices of stakeholders. The complete stakeholder views on adaptation measures are a consequence of their recurrent exposure to water limitations under the current climate. The range of options identified include agronomic, water management, and governance measures. The measures related to water management are then selected to provide an quantitative estimation on their effectiveness with the WAAPA model in the third step.

The approach links perceptions on the potential effect of the measure with a quantification by means of a water policy model. We focus on options that presented a high degree of disagreement among the stakeholders groups (Table 3). The application of the WAAPA model to these choices helped clarify the objective effect of the options. Furthermore, the WAAPA model was also used to simulate policy options that could be implemented in other sectors, e.g., urban or ecosystems, since these choices could bring a quantitative perspective to compare the local community choices.

The Adaptation Policy 1 addressed to improve water urban use could reach major improvements of water availability for irrigation and in turn avoid reduced water for environmental use by adaptation policy 2 . The use of additional water infrastructure for irrigation (e.g., from hydropower reservoirs) was performed by the adaptation policy 3 . The simulations showed that the effect for improving water availability of policy 3 was not significant. Adaptation options to improve the water managements by interconnections (a new pipeline connecting upstream water bodies to the rice fields, additional releases from upstream reservoirs or transfer of water) were endorsed into adaptation policy 4 . The adoption of policy 4 was specially controversy between stakeholders in their acceptance, however the simulations clearly showed improvement of less than $20 \%$ except in a few sub-basins and scenarios.

\section{Conclusions}

Policy is deeply involved in the water sector. Usually, policy development is based on an historical analysis of water demand and supply. It is therefore a challenge to develop policies that respond to an 


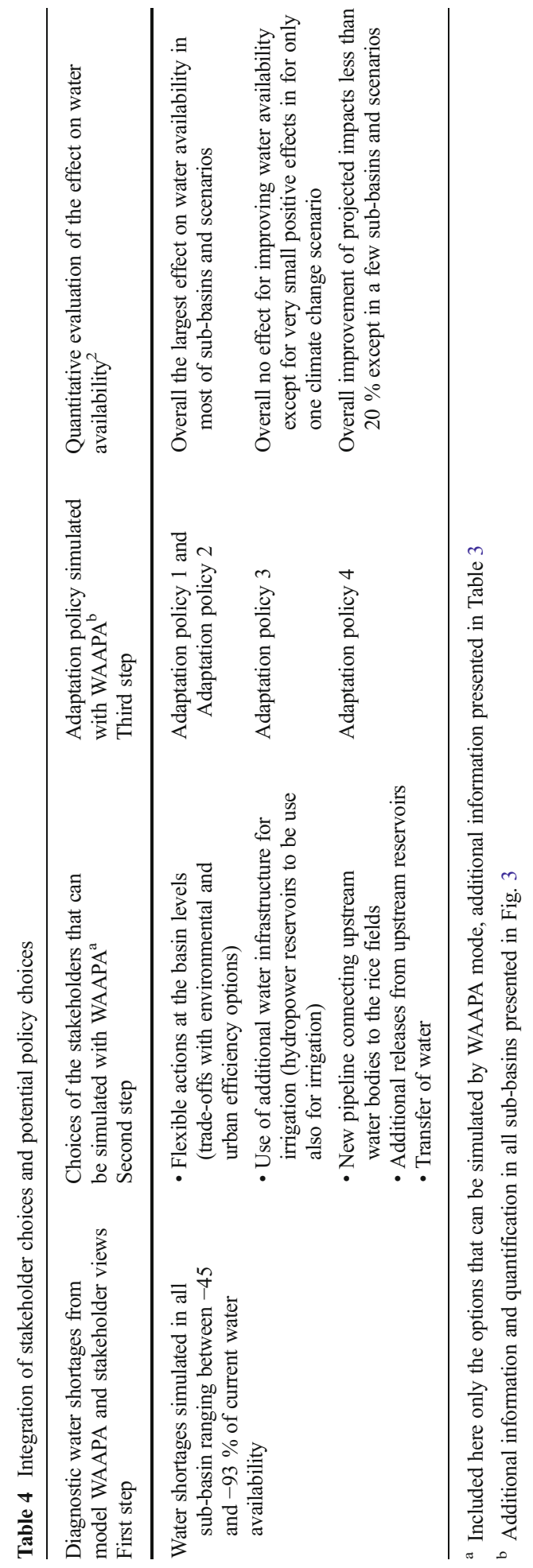


uncertain future. Indeed, science-policy integration is one of the most complex challenges that the scientific and policy making communities face since it involves knowledge sharing and ex-change among a wide range of disciplines and actors (Quevauviller et al. 2005). Despite these challenges, it is possible to achieve this goal and there are success stories throughout the world.

In this study we have attempted to face part of this challenge by presenting an approach that assesses how people - water policy and local actors - may influence water in the costal wetland under climate change. Together - policy and stakeholder choices - may be useful in singling out areas for moving towards adaptation and dialogue. This information may be used to implement and develop policy.

We recognise that the data needs for developing such a decision-making tool are complex and may be hard to satisfy; nevertheless, the conceptual steps that are presented remain valid and may be undertaken at a simplified level. Moreover, since the kinds of policy decisions being considered are at a local level it is likely that the availability of data will be greater.

Qualitative information from participatory research can be of great value in climate change adaptation and policy making when is combined with other tools or models to generate quantitative information (van Aalst et al. 2008). Recent researches have combined both methods to assess and identify climate change risk and adaptation options with valuable results on the adoption of a local adaptation strategy (Picketts et al. 2013; Cohen et al. 2006). Tisdell (2010) evaluated the implications of different water policy options in a semiarid area of Australia by modelling and found that the most cost effective option was a reduction of the water allocation to entitlement holders in order to increase water available for environmental use. Similarly to our study, Cohen et al. (2006) identified, by combining computer-based models and participatory research in the Okanagan Basin (Canada), a portfolio of adaptation options for water resources management rather than seeking consensus on the "best" option or process. Méndez et al. (2012) explored the historical records of the Doñana case study to develop a tailored action research program and provide specific policy-relevant recommendations for water resources management and wetland conservation. They conclude that there is a need of flexible and adaptive institutional regimes, social research and public participation, and improved monitoring and mechanisms for information exchange among others, which seem to be quite concurrent with our findings. Palomo et al. (2011) also carried out a participative process to analyze the current and the future situation in the Donana wetland. They stressed the scarcity of water as the biggest problem and proposed consensual management strategies that include coordinated local plans and increased professional training. Participatory research can help to advance adaptation planning since knowing and doing is linked through action (Moser and Elkstrom 2011; Picketts et al. 2013).

Climate change is a global challenge with increasing severe consequences at the local level. In the Lower Guadalquivir River Basin District, existing water conflicts between the rice farming and the natural ecosystem are expected to be intensified in the future due to projected scenarios of water availability reduction and higher temperatures. This study aims to identify flexible climate change adaptation options in the Doñana coastal wetlands by simulating water availability to farmers with the WAAPA model and by engaging informed stakeholders in the assessment process. The combination of both methodologies approaches the potential adaptation options to the local environmental, social and policy context.

Results suggest that perception on new water infrastructure and farming subsidies dominates the decision process. Information provided during the study shaped the final adaptation options developed. Our research contributes to the definition of sustainable water management for rice production, livelihood support and the environment. 
Results from the consulting process showed how the accelerated state of climate change is already affecting the rice production and the natural ecosystem in the Doñana wetland and what are the main conflicts and agreements on adaptation options under water availability reductions. The water scarcity and the water quality deterioration were perceived by all the informants as the major risks for the good functioning of both the rice farming and the natural ecosystem. Rice farmers do not recognize higher temperatures as a risk to be concerned, but they are already changing the rice growing calendar and introducing new varieties which are more tolerant to heat stress. The rice farming is a highly mechanized and organized agricultural system and rice farmers have a high education level. However, they seem to have a shot-term view of risks and they do not necessarily link them to climate change. Reductions of water availability together with the large water need to irrigate the rice fields and to control the water salinity will raise the current conflict between water users from different economic activities and the natural ecosystem conservation.

There is a shared perception on the need of new and diverse local initiatives to face the increasing water scarcity and salinity risk. The decision making processes of adaptation options is variable according to the stakeholder views. Farmers Association decisions are mainly dominated by technological and profit-driven principles with preference on new water infrastructure and farming subsidies. The lack of generational renewal by the decreasing number of young farmers and the new environmental requirements from CAP can bring more pressure on local farmers' price support. Environmentalists showed reluctance to those options which may result in higher economic costs and environmental impacts due to new infrastructures. Environmentalists and administration actors supported the reduction of rice cultivated area as an effective adaptation option. All the actors and the experts emphasized the important role that could play improved institutional governance and the need of encouraging the farmers' long-term views by climate change advisement and capacity building.

Acknowledgments This research was supported by the Spanish Biodiversity Foundation project of Adaptation in Doñana, implemented and coordinated by WWF-Spain and the BASE project of the 7th Framework Programme of the European Commission (http://base-adaptation.eu/). We acknowledge the helpful comments of two anonymous reviewers.

\section{Appendix 1. Guidelines for the Interviews}

\section{Objective of the Research}

Coastal systems in the North-east Atlantic Ocean are expected to experience adverse impacts due to projected sea-level rise and climate change. There is a need to improve the planning by assessment of coastal vulnerability and flexible adaptation from the local scale and engage widely with relevant stakeholders.

The main goal of this research is to assess the climate change risk and what are the potential adaptation options in the Doñana coastal wetlands, a world heritage and biodiversity site with an intensive agricultural activity under scarcity conditions. We aimed to contribute to adaptation plans development in the case study region including the participation of informed stakeholders. The research was completed within the Spanish Biodiversity Foundation project of Adaptation in Doñana, implemented and coordinated by WWF-Spain. 


\section{Methodology}

The interviews aimed to draw a broad outline of the case study's vulnerability based on the expertise and knowledge of local actors and develop a range of flexible adaptation options according to the local environmental, social and policy context.

The interview survey was conducted across different days in February 2012 and eleven key participants from relevant sectors of the coastal wetland were encouraged to give their input. The requirements for the participants' selection were: i) to be working on activities related to the rice production and the natural ecosystem during the last decade; ii) to have an extensive knowledge about the rice productive sector and to have regular contact with the rice farmers; ii) to have an extensive knowledge about the welfare of the wetland and the natural ecosystem functioning; and iii) to be informed on the water management requirements to cope successfully with the rice production and the natural ecosystem.

\section{Interview Questions}

Type of question
Introduction
Perception of climate change
risks/impacts for the rice
farming and the natural
ecosystem

Perception of flexible adaptation options for the rice farming and the natural ecosystem
Selected interview question

Q1: Name

Q2: Background and experience in the region

Q3: Employment status

Q4: Do you feel that the Doñana socio-environmental system has changed due to climate variability or extreme events (droughts, heat waves, rainfall distributions) over the last 20 years? (E.g. severe droughts of 1979/80, $1991 / 95$ or $2004 / 05)$ ?

Q5: Have you noticed changes in the yields or the growing cycle (shortening/ lengthening) of rice crops in the wetland?

Q6: Have you noticed changes in the presence or occurrence of pests, weeds and diseases?

Q7: Have you noticed changes in the management (e.g., operations, irrigation, use of fertilizers/sprays) of rice crops?

Q8: Have you noticed river hydro morphological alterations or changes in the water availability and quality (e.g., salinity of water) in the region?

Q9: Have you noticed changes in the distribution of natural vegetation and wildlife?

Q10: What factor do you consider as the most harmful for the rice farming and the natural ecosystem in the region?

Q11: What measures have been implemented to tackle climate variability and climate change?

Q12: What strategies have been implemented to ensure water availability?

Q13: What importance do you consider that may have strategies to increase water savings?

Q14: What adaptation options do you consider the most effective for the rice farming and the natural ecosystem in the region?

Q15: What are the main drivers and tools to undertake these adaptation measures and strategies?

Q16: What are the main barriers to the implementation of climate change adaptation options in the region?

Other comments
Q17: Are there any other issues that you consider important in relation to the climate change risks and adaptation which have not tried yet in this interview? 


\section{Appendix 2. Summary of the Responses of the Interviews}

\begin{tabular}{|c|c|c|c|}
\hline $\begin{array}{l}\text { Identification of risks } \\
\text { and adaptation options }\end{array}$ & Farmer association (5) & Administration (3) & Environmentalists (3) \\
\hline \multirow[t]{5}{*}{$\begin{array}{l}\text { Main risk for the artificial } \\
\text { rice wetland }\end{array}$} & $\begin{array}{c}\text { Decreased water } \\
\text { availability }\end{array}$ & $\begin{array}{c}\text { Decreased water } \\
\text { availability }\end{array}$ & $\begin{array}{l}\text { Decreased water } \\
\text { availability }\end{array}$ \\
\hline & $\begin{array}{l}\text { Increased water } \\
\text { salinity }\end{array}$ & Increased water salinity & Increased water salinity \\
\hline & Higher temperatures & Higher temperatures & \\
\hline & & Reductions of water stored & \\
\hline & & $\begin{array}{l}\text { Heavy rains and higher } \\
\text { deposits appearance }\end{array}$ & \\
\hline \multirow[t]{8}{*}{$\begin{array}{l}\text { Most effective } \\
\text { adaptation, overall }\end{array}$} & $\begin{array}{c}\text { Changes of water } \\
\text { management }\end{array}$ & Water saving & Energy and water savings \\
\hline & $\begin{array}{l}\text { Modernization of } \\
\text { irrigation systems }\end{array}$ & $\begin{array}{l}\text { Increased scientific } \\
\text { research, field studies } \\
\text { and transferring }\end{array}$ & $\begin{array}{l}\text { Increased scientific } \\
\text { research, field studies } \\
\text { and farmers training }\end{array}$ \\
\hline & $\begin{array}{l}\text { Water recirculation and } \\
\text { reutilization within } \\
\text { the paddy }\end{array}$ & $\begin{array}{l}\text { Improved coordination } \\
\text { between institutions, } \\
\text { aggregated of the } \\
\text { information and } \\
\text { dissemination }\end{array}$ & $\begin{array}{l}\text { Strategies to conserve } \\
\text { biodiversity and ensure } \\
\text { the provision of } \\
\text { ecosystem services }\end{array}$ \\
\hline & $\begin{array}{l}\text { New dams } \\
\text { construction } \\
\text { and other water } \\
\text { infrastructures }\end{array}$ & $\begin{array}{l}\text { Improved monitoring } \\
\text { and information } \\
\text { on water use }\end{array}$ & $\begin{array}{l}\text { Regulations from WFD } \\
\text { and the Hydrologic } \\
\text { Plan of the Guadalquivir } \\
\text { River Basin }\end{array}$ \\
\hline & & $\begin{array}{l}\text { Reduction of the cultivated } \\
\text { areas located closer to } \\
\text { the sea }\end{array}$ & $\begin{array}{l}\text { Long-term climate change } \\
\text { strategies and } \\
\text { agreements }\end{array}$ \\
\hline & & $\begin{array}{l}\text { Increased the technical } \\
\text { efficiency of the } \\
\text { irrigation systems }\end{array}$ & $\begin{array}{l}\text { Increased dissemination, } \\
\text { public participation and } \\
\text { environmental } \\
\text { awareness raising }\end{array}$ \\
\hline & & $\begin{array}{l}\text { Local climate change } \\
\text { actions }\end{array}$ & Organic agriculture \\
\hline & & $\begin{array}{l}\text { Dikes construction to } \\
\text { contain marine intrusion }\end{array}$ & \\
\hline $\begin{array}{l}\text { Responsible for } \\
\text { implementing } \\
\text { adaptation }\end{array}$ & $\begin{array}{l}\text { Administration; rice } \\
\text { farming unions } \\
\text { and cooperatives }\end{array}$ & $\begin{array}{l}\text { Administration; Rice } \\
\text { farming unions and } \\
\text { cooperatives; Research } \\
\text { groups to facilitate }\end{array}$ & $\begin{array}{l}\text { Administration; Rice } \\
\text { farming unions and } \\
\text { cooperatives; Research } \\
\text { groups to facilitate }\end{array}$ \\
\hline \multirow[t]{4}{*}{$\begin{array}{l}\text { Barriers to implement } \\
\text { adaptation }\end{array}$} & $\begin{array}{l}\text { The lack of clear } \\
\text { actions }\end{array}$ & $\begin{array}{l}\text { Rice farming conservative } \\
\text { traditions }\end{array}$ & $\begin{array}{l}\text { Rice farming conservative } \\
\text { traditions }\end{array}$ \\
\hline & $\begin{array}{l}\text { Larger reductions of } \\
\text { inputs (water, } \\
\text { fertilizers, sprays) }\end{array}$ & $\begin{array}{l}\text { The difficult for } \\
\text { generational renewal } \\
\text { and change due to aging } \\
\text { farmers' population }\end{array}$ & $\begin{array}{l}\text { The difficult for generational } \\
\text { renewal and change due } \\
\text { to aging farmers' } \\
\text { population }\end{array}$ \\
\hline & $\begin{array}{l}\text { Marine intrusion } \\
\text { during drought } \\
\text { periods }\end{array}$ & $\begin{array}{l}\text { Farmers' short-term } \\
\text { perception of risks } \\
\text { and profit-driven } \\
\text { principles }\end{array}$ & $\begin{array}{l}\text { Farmers' short-term } \\
\text { perception of risks and } \\
\text { profit-driven principles }\end{array}$ \\
\hline & $\begin{array}{l}\text { New CAP } \\
\text { environmental } \\
\text { requirements }\end{array}$ & $\begin{array}{l}\text { The lack of interest of } \\
\text { rice farmers in } \\
\text { climate change } \\
\text { issues and debates }\end{array}$ & $\begin{array}{l}\text { The lack of interest of rice } \\
\text { farmers in climate } \\
\text { change issues and } \\
\text { debates }\end{array}$ \\
\hline
\end{tabular}




\begin{tabular}{|c|c|c|c|}
\hline & Energy prices & $\begin{array}{l}\text { Easy crop management, } \\
\text { all the operations } \\
\text { are subcontracted }\end{array}$ & $\begin{array}{l}\text { Low labour needs and high } \\
\text { water comsuption }\end{array}$ \\
\hline & $\begin{array}{l}\text { Lower yields and } \\
\text { quality crops }\end{array}$ & $\begin{array}{c}\text { High subsidies } \\
\text { dependence }\end{array}$ & $\begin{array}{l}\text { The lack of environmental } \\
\text { awareness }\end{array}$ \\
\hline & Irrigation water costs & $\begin{array}{l}\text { Clay soils, risks of } \\
\text { floods }\end{array}$ & $\begin{array}{l}\text { New CAP environmental } \\
\text { requirements }\end{array}$ \\
\hline & $\begin{array}{l}\text { Extremely competitive } \\
\text { and highly volatile } \\
\text { price sector }\end{array}$ & $\begin{array}{l}\text { The unstable equilibrium } \\
\text { of the Doñana system }\end{array}$ & $\begin{array}{l}\text { The lack of accurate } \\
\text { irrigation water } \\
\text { measures (flow meters) }\end{array}$ \\
\hline \multirow[t]{4}{*}{$\begin{array}{l}\text { Risks related to } \\
\text { water scarcity }\end{array}$} & $\begin{array}{l}\text { Water availability } \\
\text { reductions }\end{array}$ & $\begin{array}{l}\text { Water availability } \\
\text { reductions }\end{array}$ & Water availability reductions \\
\hline & $\begin{array}{l}\text { Turbidity, muddy } \\
\text { water }\end{array}$ & $\begin{array}{l}\text { Turbidity, muddy } \\
\text { water }\end{array}$ & Water stored reductions \\
\hline & $\begin{array}{l}\text { Cumulative impacts } \\
\text { in the Guadalquivir } \\
\text { River Basin affect } \\
\text { the rice fields }\end{array}$ & & $\begin{array}{l}\text { Cumulative impacts in the } \\
\text { Guadalquivir River } \\
\text { Basin affect the rice } \\
\text { fields }\end{array}$ \\
\hline & Erosion problems & & \\
\hline \multirow[t]{10}{*}{$\begin{array}{l}\text { Adaptation to increased } \\
\text { water scarcity }\end{array}$} & $\begin{array}{c}\text { Changes of water } \\
\text { management }\end{array}$ & $\begin{array}{c}\text { Changes of water } \\
\text { management }\end{array}$ & $\begin{array}{c}\text { Changes of water } \\
\text { management }\end{array}$ \\
\hline & $\begin{array}{l}\text { Modernization of } \\
\text { irrigation systems }\end{array}$ & $\begin{array}{l}\text { Modernization of } \\
\text { irrigation systems }\end{array}$ & Water saving strategies \\
\hline & $\begin{array}{l}\text { Water recirculation } \\
\text { and reutilization } \\
\text { within the paddy }\end{array}$ & $\begin{array}{l}\text { Water recirculation and } \\
\text { reutilization within } \\
\text { the paddy }\end{array}$ & $\begin{array}{l}\text { Water recirculation and } \\
\text { reutilization within the } \\
\text { paddy }\end{array}$ \\
\hline & Laser levelling & $\begin{array}{l}\text { Installation of } \\
\text { flow meters }\end{array}$ & $\begin{array}{l}\text { Modernization of irrigation } \\
\text { systems avoiding new } \\
\text { water infrastructures } \\
\text { with environmental } \\
\text { impact }\end{array}$ \\
\hline & $\begin{array}{l}\text { New dams } \\
\text { construction } \\
\text { and other water } \\
\text { infrastructures }\end{array}$ & & $\begin{array}{l}\text { Efficient solutions for both } \\
\text { the rice farming and the } \\
\text { natural ecosystem }\end{array}$ \\
\hline & $\begin{array}{l}\text { Setting of irrigation } \\
\text { turns }\end{array}$ & & $\begin{array}{l}\text { Long-term agreements on } \\
\text { water and climate } \\
\text { change management } \\
\text { (water markets, water } \\
\text { use allocation permits) }\end{array}$ \\
\hline & $\begin{array}{l}\text { Increased farmers } \\
\text { training, technical } \\
\text { advice and } \\
\text { scientific } \\
\text { information }\end{array}$ & & $\begin{array}{l}\text { Actions at the basin level } \\
\text { leading flexible } \\
\text { adaptation strategies to } \\
\text { climate change }\end{array}$ \\
\hline & $\begin{array}{l}\text { New rice varieties } \\
\text { adapted to water } \\
\text { and heat stress }\end{array}$ & & $\begin{array}{l}\text { Regulations from WFD } \\
\text { and the Hydrologic } \\
\text { Plan of the } \\
\text { Guadalquivir River } \\
\text { Basin }\end{array}$ \\
\hline & $\begin{array}{l}\text { Installation of flow } \\
\text { meters }\end{array}$ & & \\
\hline & $\begin{array}{l}\text { Reduced energy } \\
\text { costs }\end{array}$ & & \\
\hline $\begin{array}{l}\text { Perception of the } \\
\text { importance of }\end{array}$ & High & High & High \\
\hline
\end{tabular}

Easy crop management ll the operations

igh subsidies

soils, risks of

xtremely competitive and highly volatile price secto

Water availability reductions

urbidity, muddy in the Guadalquivir River Basin affect the rice field

sion problems odernization of ater recirculation and reutilization within the paddy

New dams and other wate etting of irrigation turns

water saving ncreased farmers advice and scientific

ew rice varieties adapted to water and heat stress

nstallation of flow duced energy cost ater availability

urbidity, muddy

water

anges of water

odernization of

Water recirculation and reutilization within

flow

High

ong-term agreements on (water markets, water tions at the basin leve daptation strategies to egulations from WFD and the Hydrologic of the Guadalquivir River Basin 


\begin{tabular}{|c|c|c|c|}
\hline \multirow{3}{*}{$\begin{array}{l}\text { Risk related to } \\
\text { increased salinity }\end{array}$} & Increased soil salinity & Increased soil salinity & Increased soil salinity \\
\hline & $\begin{array}{c}\text { Increased salinity } \\
\text { in the aquifer }\end{array}$ & $\begin{array}{c}\text { Increased salinity } \\
\text { in the aquifer }\end{array}$ & $\begin{array}{l}\text { Increased salinity in the } \\
\text { aquifer }\end{array}$ \\
\hline & & & Biodiversity losses \\
\hline \multirow[t]{3}{*}{$\begin{array}{l}\text { Adaptation to } \\
\text { increased salinity }\end{array}$} & $\begin{array}{l}\text { Dam water releases } \\
\text { upstream from } \\
\text { the rice area }\end{array}$ & $\begin{array}{l}\text { Dam water releases } \\
\text { upstream from the } \\
\text { rice area }\end{array}$ & $\begin{array}{l}\text { Dam water releases upstream } \\
\text { from the rice area }\end{array}$ \\
\hline & $\begin{array}{l}\text { Flooding irrigation } \\
\text { systems to } \\
\text { wash soils }\end{array}$ & & $\begin{array}{l}\text { Organic production (good } \\
\text { farming practices) }\end{array}$ \\
\hline & $\begin{array}{l}\text { New pipeline to bring } \\
\text { in the water directly } \\
\text { upstream from the } \\
\text { salt water intrusion }\end{array}$ & & \\
\hline $\begin{array}{l}\text { Risk related to } \\
\text { increased invasive } \\
\text { species, pests } \\
\text { and diseases }\end{array}$ & $\begin{array}{l}\text { Ineffectiveness of } \\
\text { current plant } \\
\text { protection products }\end{array}$ & & Biodiversity losses \\
\hline $\begin{array}{l}\text { Adaptation to increased } \\
\text { invasive species, } \\
\text { pests and diseases }\end{array}$ & Integrated production & Integrated production & Integrated production \\
\hline \multirow{2}{*}{$\begin{array}{l}\text { Risk related to } \\
\text { decreased rice } \\
\text { productivity } \\
\text { and quality }\end{array}$} & $\begin{array}{l}\text { Reduction of the rice } \\
\text { cultivated areas }\end{array}$ & $\begin{array}{l}\text { Reduction of the rice } \\
\text { cultivated areas }\end{array}$ & $\begin{array}{l}\text { Reduction of the rice } \\
\text { cultivated areas }\end{array}$ \\
\hline & Lower income & & \\
\hline \multirow[t]{4}{*}{$\begin{array}{l}\text { Adaptation to decreased } \\
\text { productivity and quality }\end{array}$} & $\begin{array}{l}\text { Changes of the } \\
\text { management } \\
\text { (integrated } \\
\text { production) }\end{array}$ & $\begin{array}{l}\text { Changes of the } \\
\text { management } \\
\text { (integrated } \\
\text { production) }\end{array}$ & $\begin{array}{l}\text { Changes of the management } \\
\text { (integrated production) }\end{array}$ \\
\hline & $\begin{array}{l}\text { New longer cycle rice } \\
\text { varieties (J-sendra } \\
\text { de } 155 \text { or Puntal } \\
145)\end{array}$ & $\begin{array}{l}\text { Improved } \\
\text { commercialization }\end{array}$ & $\begin{array}{l}\text { New varieties but not } \\
\text { including those GMOs }\end{array}$ \\
\hline & $\begin{array}{l}\text { Modernization and } \\
\text { innovative technical } \\
\text { measures }\end{array}$ & $\begin{array}{c}\text { Farmers training and } \\
\text { environmental } \\
\text { awareness raising }\end{array}$ & $\begin{array}{c}\text { Farmers training and } \\
\text { environmental } \\
\text { awareness raising }\end{array}$ \\
\hline & & & $\begin{array}{l}\text { Improved the product } \\
\text { processed to be exported } \\
\text { (organic products) }\end{array}$ \\
\hline
\end{tabular}

\section{References}

Aguilar M (2010) Producción integrada del arroz en el sur de España. Consejería de Agricultura y Pesca. ISBN 978-84-8474-290-6. Junta de Andalucía. 320 pp

Berbel J, Mesa-Jurado MA, Pistón JM (2011) Value of irrigation water in Guadalquivir Basin (Spain) by residual value method. Water Resour Manag 25:1565-1579

Berrang-Ford L, Ford JD, Lesnikowski A, Poutiainen C, Barrera M, Heymann SJ (2014) What drives national adaptation? A global assessment. Clim Chang 1-10

Bryson JM (2004) What to do when stakeholders matter: stakeholder identification and analysis techniques. Public Manag Rev 6(1):21-53

Carlsen B, Glenton C (2011) What about N? A methodological study of sample-size reporting in focus group studies. BMC Med Res Methodol 11(1):26 
CHE (2014) Plan Hidrológico de la demarcación hidrográfica del Ebro, aprobado por Real Decreto 129/2014. Ebro Hydrologic Basin Authority, Spanish Ministry of the Environment, Madrid. Available online at: www. chebro.es

CHG (2013) Plan Hidrológico de la demarcación hidrográfica del Guadalquivir, aprobado por Real Decreto 355/ 2013. Guadalquivir Hydrologic Basin Authority, Spanish Ministry of the Environment, Madrid. Available online at: www.chguadalquivir.es

Cohen S, Neilson D, Smith S et al (2006) Learning with local help: expanding the dialogue on climate change and water management in the Okanagan region, British Columbia, Canada. Clim Chang 75:331-358

Cummings JL, Doh J (2000) Identifying who matters: mapping key players in multiple environments. Calif Manag Rev 42(2):83-104

De Stefano L, Hernandez Mora N, Iglesias A, Sánchez B (2014) Water for rice farming and biodiversity: exploring choices for adaptation to climate change in Doñana, southern Spain. In: Stucker D, Lopez-Gun E (eds) Adaptation to Climate Change through Water Resources Management: Capacity, Equity, and Sustainability. Routledge / Earthscan, Oxford

Eden C, Ackermann F (1998) Analysing and comparing idiographic causal maps. Managerial and organisational cognition. Theory Method Res 192-209

EEA (2012) European waters - current status and future challenges. Synthesis Report No 9/2012. European Environment Agency, Copenhagen, $52 \mathrm{pp}$

Freeman RE (1984) Strategic management: A stakeholder approach. Cambridge University Press

García Novo F, Marín Cabrera C (2006) Doñana: Water and Biosphere, Doñana 2005 Project. Guadalquivir Hydrologic Basin Authority, Spanish Ministry of the Environment, Madrid

García-Llorente M, Martín-López B, Montes C (2011) Exploring the motivations of protesters in contingent valuation: insights for conservation policies. Environ Sci Pol 14(1):76-88

Garrick D, Siebentritt MA, Aylward B, Bauer CJ, Purkey A (2009) Water markets and freshwater ecosystem services: policy reform and implementation in the Columbia and Murray-Darling Basins. Ecol Econ 69(2): 366-379

Garrote L, Iglesias A, Granados A, Mediero L, Martín-Carrasco F (2015) Quantitative assessment of climate change vulnerability of irrigation demands in Mediterranean Europe. Water Resour Manag 29(2):325-338

Garrote L, Iglesias A, Martín-Carrasco F, Mediero L (2011) WAAPA: A model for water availability and climate change adaptation policy analysis. Proceedings of the VI EWRA International. Symposium - Water Engineering and Management in a Changing Environment, Catania

Glicken J (2000) Getting stakeholder participation 'right': a discussion of participatory processes and possible pitfalls. Environ Sci Pol 3(6):305-310

Gonzalez-Zeas D, Garrote L, Iglesias A, Sordo-Ward A (2012) Improving runoff estimates from regional climate models: a performance analysis in Spain. Hydrol Earth Syst Sci 16:1709-1723

Hanak E, Lund JR (2012) Adapting California's water management to climate change. Clim Chang 111(1):17-44

Harrell MC, Bradley MA (2009) Data collection methods. Semi-structured interviews and focus groups. Rand National Defense Research Institute, Santa Monica

Iglesias A (2009) Policy issues related to climate change in Spain. In: Dinar A, Albiac A (eds) Policy and strategic behaviour in water resource management. Earthscan, London

Iglesias A, Cancelliere A, Cubillo F, Garrote L, Wilhite DA (2008a) Coping with drought risk in agriculture and water supply systems: Drought management and policy development in the Mediterranean. Springer, The Netherlands

Iglesias A, Garote L, Flores F, Moneo M (2007) Challenges to manage the risk of water scarcity and climate change in the Mediterranean. Water Resour Manag 21:775-788

Iglesias A, Garrote L, Quiroga S, Moneo M (2012) From climate change impacts to the development of adaptation strategies: challenges for agriculture in Europe. Clim Chang 112:143-168. doi:10.1007/ s10584-011-0344-X

Iglesias A, Moneo M, Garrote L, Flores F (2008b) Drought and water scarcity: current and future vulnerability and risk. In: Garrido A, Llamas MR (eds) Issues in Water Resource Policy, Resources for the Future. Washington, DC

Ingram J, Morris C (2007) The knowledge challenge within the transition towards sustainable soil management: an analysis of agricultural advisors in England. Land Use Policy 24(1):100-117

IPCC (2013) Climate Change 2013: The Physical Science Basis. In: Stocker TF, Qin D, Plattner GK, Tignor M, Allen SK, Boschung J, Nauels A, Xia Y, Bex V, Midgley PM (eds) Contribution of Working Group I to the Fifth Assessment Report of the Intergovernmental Panel on Climate Change. Cambridge University Press, Cambridge, $1535 \mathrm{pp}$

IPCC (2014) Summary for policymakers. In: Field CB, Barros VR, Dokken DJ, Mach KJ, Mastrandrea MD, Bilir TE, Chatterjee M, Ebi KL, Estrada YO, Genova RC, Girma B, Kissel ES, Levy AN, MacCracken S, Mastrandrea PR, White LL (eds) Climate Change 2014: Impacts, Adaptation, and Vulnerability. Part A: 
Global and Sectoral Aspects. Contribution of Working Group II to the Fifth Assessment Report of the Intergovernmental Panel on Climate Change. Cambridge University Press, Cambridge, pp 1-32

Jones L (2010) Overcoming social barriers to adaptation. ODI Background Note. London: ODI (www.odi.org. uk/resources/download/4945.pdf)

Martín-López B, García-Llorente M, Palomo I, Montes C (2011) The conservation against development paradigm in protected areas: valuation of ecosystem services in the Doñana social-ecological system (southwestern Spain). Ecol Econ 70:1481-1491

Méndez PF, Isendahl N, Amezaga JM, Sanamaria L (2012) Facilitating transitional processes in rigid institutional regimes for water management and wetland conservation: experience from the Guadalquivir Estuary. Ecol Soc 17(1):26

Moser SC, Elkstrom JA (2011) Taking ownership of climate change: participatory adaptation planning in two local case studies from California. J Environ Stud Sci 1:63-74

Nakicenovic N, Alcamo J, Grubler A, Riahi K, Roehrl RA, Rogner H-H, Victor N et al (2000) Special Report on Emissions Scenarios (SRES). A Special Report of Working Group III of the Intergovernmental Panel on Climate Change. Cambridge University Press, Cambridge

OECD (2012) Looking to 2060: Long-term global growth prospects. OECD, Paris

Ojeda J, Álvarez JI, Martín D, Fraile P (2009) El uso de las TIG para el cálculo del índice de vulnerabilidad costera (CVI) ante una potencial subida del nivel del mar en la costa andaluza (España). GeoFocus, 9, 83100. ISSN - 1578-5157

Palmer MA, Reidy Liermann CA, Nilsson C, Flörke M, Alcamo J, LakePS BN (2008) Climate change and the world's river basins: anticipating management options. Front Ecol Environ 6(2):81-89

Palomo I, Martín-López B, López-Santiago C, Montes C (2011) Participatory scenario planning for protected areas management under the ecosystem services framework: the Doñana social-ecological system in southwestern Spain. Ecol Soc 16(1):23

Picketts IM, Curry J, Déry SJ, Cohen SJ (2013) Learning with practitioners: climate change adaptation priorities in a Canadian community. Clim Chang 118(2):321-337

Pulido-Calvo I, Gutiérrez-Estrada JC, Savic D (2012) Heuristic modelling of the water resources management in the Guadalquivir River Basin, Southern Spain. Water Resour Manag 26(1):185-209

Quevauviller P, Balabanis P, Fragakis C, Weydert M, Oliver M, Kaschl A, Arnold G, Kroll A, Galbiati L, Zaldivar JM, Bidoglio G (2005) Science-policy integration needs in support of the implementation of the EU water framework directive. Environ Sci Pol 8(3):203-211

Ramieri E, Hartley A, Barbanti A, Duarte Santos F, Gomes A, Hilden M, Laihonen P, Marinova N, Santini M (2011) Methods for assessing coastal vulnerability to climate change. European Topic Centre on Climate Change Impacts, Vulnerability and Adaptation (ETC. CCA) Technical Paper, Bologna (IT) 93 pp

Reed MS, Fraser ED, Dougill AJ (2006) An adaptive learning process for developing and applying sustainability indicators with local communities. Ecol Econ 59(4):406-418

Rey D, Garrido A, Calatrava J (2014). The Water Markets in Spain: moving towards 21st century mechanisms and approaches with 20th century regulations. In: Easter W. and Huang Q. (eds) Water Markets for the 21st. Century: What Have We Learned? Springer, pp 127-147

Rijsberman FR (2006) Water scarcity: fact or fiction? Agric Water Manag 80(1):5-22

Sánchez B, Álvaro-Fuentes J, Cunningham R, Iglesias A (2014a). Towards mitigation of greenhouse gases by small changes in farming practices: understanding local barriers in Spain. Mit Adapt Strateg Glob Chang 134. doi:10.1007/s11027-014-9562-7

Sánchez B, Rasmussen A, Porter JR (2014b) Temperatures and the growth and development of maize and rice: a review. Glob Chang Biol 20(2):408-417

Sandelowski M (1995) Sample size in qualitative research. Res Nur Health 18(2):179-183

Sharma D, Das Gupta A, Babel MS (2007) Spatial disaggregation of bias-corrected GCM precipitation for improved hydrological simulation: Ping river basin, Thailand. Hydrol Earth Syst Sci 11(4):1373-1390

Tisdell J (2010) Acquiring water for environmental use in Australia: an analysis of policy options. Water Resour Manag 24(8):1515-1530

van Aalst MK, Cannon T, Burton I (2008) Community level adaptation to climate change: the potential role of participatory community risk assessment. Glob Environ Chang 18:165-179

Varis O, Kajander T, Lemmela R (2004) Climate and water: from climate models to water resources management and vice versa. Clim Chang 66:321-344

Wei Y, Langford J, Willett IR, Barlow S, Lyle C (2011) Is irrigated agriculture in the Murray Darling Basin well prepared to deal with reductions in water availability? Glob Environ Chang 21(3):906-916

Willaarts BA, Ballesteros M, Hernández-Mora N (2014) Ten years of the Water Framework Directive in Spain: An overview of the ecological and chemical status of surface water bodies. In: Martínez-Santos P, Aldaya MM, Llamas MR (eds) Integrated Water Resources Management in the 21st Century: Revisiting the paradigm. Taylor and Francis, Leiden, pp 99-120 